\title{
Media Online Untuk Mendukung Pengembangan Sociopreneur Di Era Disruptif
}

\author{
Artika Surniandari ${ }^{1}$; Hilda Rachmi ${ }^{2}$; Ahmad Al Kaafi ${ }^{3}$; Amir $^{4}$ \\ ${ }^{1}$ Sistem Informasi PSDKU Kota Surakarta \\ Universitas Bina Sarana Informatika \\ Artika.ats@bsi.ac.id \\ ${ }^{2}$ Sistem Informasi PSDKU Kota Bogor \\ Universitas Bina Sarana Informatika \\ Hilda.hlr@bsi.ac.id \\ ${ }^{3}$ Sistem Informasi PSDKU Kota Tegal \\ Universitas Bina Sarana Informatika \\ Ahmad.akf@bsi.ac.id \\ ${ }^{4}$ Sistem Informasi PSDKU Kota Pontianak \\ Universitas Bina Sarana Informatika \\ Amir.amr@bsi.ac.id
}

Cara Sitasi: Surniandari, A., Rachmi, H., Al Kaafi, A., \& Amir. (2019, Maret). Media Online Untuk Mendukung Pengembangan Sociopreneur Di Era Disruptif. (S. Dalis, Ed.) Paradigma - Jurnal Komputer dan Informatika, 21(1). doi:10.31294/p.v21i1.4730

\begin{abstract}
Technological developments in this disruptive era play an important role because of changes caused by new inventions and innovations that are in need of deep information technology development. Entrepreneurship is a field that has received special attention for some time government, education and the general public because being an entrepreneur is considered to be able to decide queue for job seekers and open new jobs. Being an entrepreneur is not always the benefits sought to become social entrepreneurs who are the goal are goodness and progress for many people. With qualitative methods we try to examine behavior, perceptions, motivations and actions sociopreneur in Bogor and observed the use of information technology in the development of sociopreneurship that. In its development to become a sociopreneur, it is hoped that it can create innovations that can create change.
\end{abstract}

Kata Kunci: Entrepreneur, media, Sociopreneur

\section{PENDAHULUAN}

Menjadi pekerja mungkin bagi sebagian orang sudah bukan merupakan target masa depannya lagi karena selain persaingan para pencari kerja semakin berat juga semakin banyak orang yang melihat peluang usaha dibalik maraknya pasar bebas.

Peluang usaha yang dimaksud adalah kesempatan membuka lapangan pekerjaan dengan menggunakan modal yang dimiliki perorangan atau kelompok untuk menghasilkan produk atau pelayanan jasa dengan maksud mendapatkan keuntungan. Lain halnya dengan sociopreneur atau wirausaha sosial, Sociopreneur merupakan penggabungan dari dua buah kata, yaitu social dan entrepre-neur. Secara ringkas, Praszkier et al.(2009) mendefinisikan sociopreneur sebagai individu yang mampu membuat perubahan sosial dalam skala makro melalui pelibatan masyarakat akar rumput. Martin dan Osberg (dalam Praszkier et al., 2009) menambahkan bahwa socio-preneurberbeda dengan aktivis sosial. Efek perubahan sosial yang dilakukan oleh socio-preneurbersifat jangka panjang, stabil, dan mendalam, sementara aktivis sosial hanya berjuang di tingkat permukaan saja.(Malilang, 2008) Pengembangan wirausaha sosial adalah bukan lain untuk meningkatkan kesejahteraan masyarakat yang ada di lingkungan tersebut. 


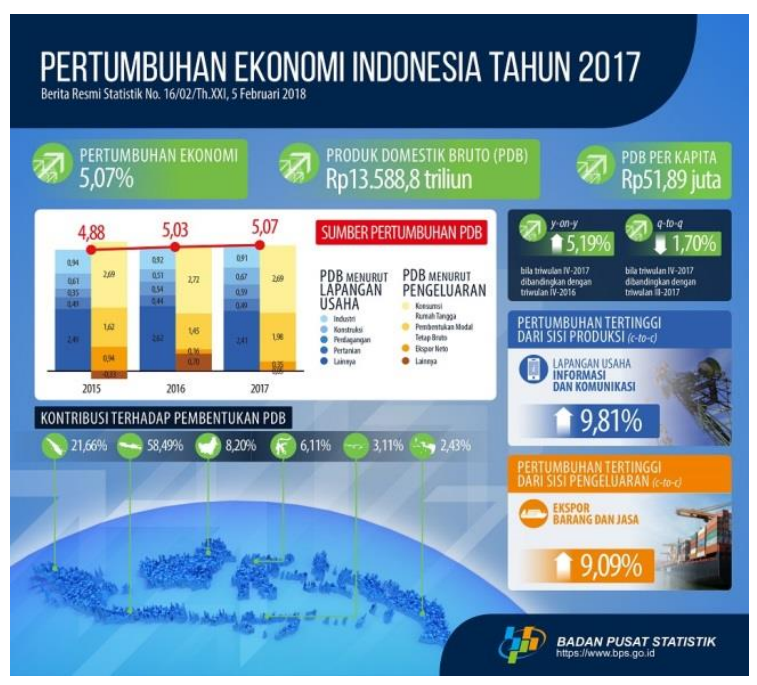

Sumber : Badan Pusat Statistik (2018)

Gambar 1. Data Pertumbuhan Ekonomi Indonesia tahun 2017

Menurut badan pusat statistik digambarkan ekonomi Indonesia tahun 2017 tumbuh 5,07 persen lebih tinggi dibanding capaian tahun 2016 sebesar 5,03

persen. Dari sisi produksi, pertumbuhan tertinggi dicapai oleh Lapangan Usaha Informasi dan Komunikasi sebesar 9,81 persen. Dari sisi pengeluaran pertumbuhan tertinggi dicapai oleh Komponen Ekspor Barang dan Jasa sebesar 9,09 persen.

Menjadi seseorang yang mampu mengesampingkan kepentingan pribadi untuk orang banyak dan menyadari bahwa memiliki usaha melalui wirausaha sosial ini tidak dapat mengharapkan keuntungan yang pasti kerena pada intinya kegiatan ini dilaksanakan untuk mencapai kesejahteraan bersama. Menariknya kegiatan sociopreneur ini apakah dapat berjalan di era disruptif saat ini yang membutuhkan inovasi untuk dapat bertahan.

Dalam penelitiannya (Gandhi \& Raina, 2018) mengemukakan "Kewirausahaan sosial terdiri dari sistem improvisasi, merancang pendekatan baru, menangkap peluang yang dilewatkan orang lain dan menghasilkan solusi untuk mengubah masyarakat menjadi lebih baik".

Inovasi disrutif atau disruptive inovation merupakan inovasi yang berhasil mentransformasi suatu sistem atau pasar yang eksisting, dengan memperkenalkan kepraktisan, kemudahan akses, kenyamanan, dan biaya yang ekonomis. Istilah ini dilontarkan pertama kalinya oleh Clayton M. Christensen dan Joseph Bower di tahun 1995. "Disruptive Technologies: Catching the Wave",
Harvard Business Review (1995). Inovasi Disruptif ini biasanya mengambil segmen pasar tertentu yang kurang diminati atau dianggap kurang penting bagi penguasa pasar, namun inovasinya bersifat breakthrough dan mampu meredefinisi sistem atau pasar yang eksisting. (Kennedy, 2017)

\section{METODE PENELITIAN}

Metode penelitian yang digunakan dalam penulisan ini adalah metode kualitatif. Metode kualitatif adalah penelitian yang bermaksud untuk memahami fenomena tentang apa yang dialami oleh subjek penelitian misalnya perilaku, persepsi, motivasi, tindakan dll. Secara holistic dan dengan cara deskripsi dalam bentuk kata kata dan bahasa pada suatu konteks khusus yang alamiah dan dengan memanfaatkan berbagai metode alamiah (Moleong dalam (Surniandari, 2017))

Teknik pengumpulan data yang digunakan dalam penelitian kualitiatif ini adalah Observasi atau pengamatan Observasi adalah pengamatan secara langsung pada objek yang akan diteliti dalam hal ini penulis mengamati aktifitas yang dilaksanakan oleh para socioprener Indonesia yang telah menjalankan usahanya dan melakukan perubahan.

Untuk mendapatkan data dan keterangan tentang sejarah dan perkembangan yayasan mata pena kami juga melakukan tanya jawab dengan pendiri yayasan mata pena serta mengamati media sosial yang digunakan untuk mempromosikan produknya serta mencari informasi melalui pemberitaan yang sudah ditayangkan beberapa portal berita di daerah tempat yayasan ini melaksanakan kegiatannya.

\section{HASIL DAN PEMBAHASAN}

\section{Inovasi Disruptif}

Menjadi seorang pengusaha di era globalisasi saat ini mengharuskan seseorang memiliki kretifitas yang tinggi dengan ide yang mungkin dianggap tak lazim namun dapat menghasilkan produk atau jasa yang bermanfaat dan dapat diterima masyarakat.

Kata disruptif itu sendiri beberapa waktu ini menjadi tren dan perbincangan di dunia bisnis sebagai patokan pencapaian yang melibatkan hasil dari pemikiran yang mungkin dapat menjawab tantangan masa depan untuk persainga di dunia usaha.

Untuk menghasilkan perubahan dibutuhkan inovasi, inovasi sebagai perwujudan ide dan kreatifitas yang digunakan untuk menciptakan sebuah pembaharuan. Inovasi Disruptif dapat diartikan sebagai penemuan baru dalam bidang usaha yang dapat membawa perubahan terhadap lingkungan dan masyarakat yang memanfaatkan inovasi tersebut. 


\section{Sociopreneur sebagai Bagian dari Entrepreneur}

Orang yang memiliki usaha sendiri di bidang produksi barang atau jasa adalah definisi dari entrepreneur di mana modal, ide, jalannya usaha dikelola oleh perorangan atau kelompok dengan mengharapkan keuntungan dari usahanya tersebut.

Lain halnya dengan sociopreneur sebelum sampai pada definisi sociopreneur kita harus mengetahui dulu ada bagian yang hampir berkaitan yaitu kegiatan sosial yang dikelola sebuah lembaga sosial dimana sebuah lembaga sosial melakukan kegiatan yang melibatkan orang lain untuk dapat menghasilkan manfaat bagi sebagian yang lain tanpa mengharapkan imbalan atau balas jasa murni sebagai upaya memberikan kebaikan dan manfaat bagi orang lain.

Sosiopreneur adalah seseorang memiliki jiwa sosial dengan kretifitasnya menciptakan sebuah usaha yang melibatkan orang lain untuk menciptakan suatu produk atau jasa yang dapat menghasilkan manfaat dan kebaikan bagi yang lain dan mengesampingkan keuntungan pribadi.

Menurut (Gandhi \& Raina, 2018) "social entrepreneurship secara mencolok terpisah dari berbagai jenis jalur kewirausahaan saat ini karena proposisi nilainya dan kenyataan bahwa ia memberikan uang untuk membuat hati dan tujuan sosial yang mulia”.

Berikut ilustrasinya dalam gambar mengenai konsep dan hubungan antara sociopreneur dengan Entrepreneur :

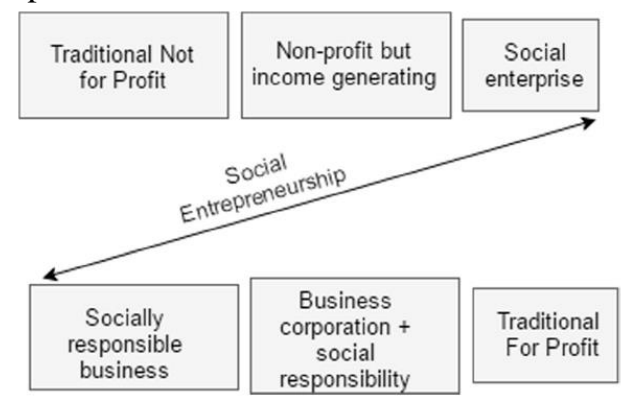

Sumber: (Gandhi \& Raina, 2018)

Gambar 2. Konsep Sociopreneur

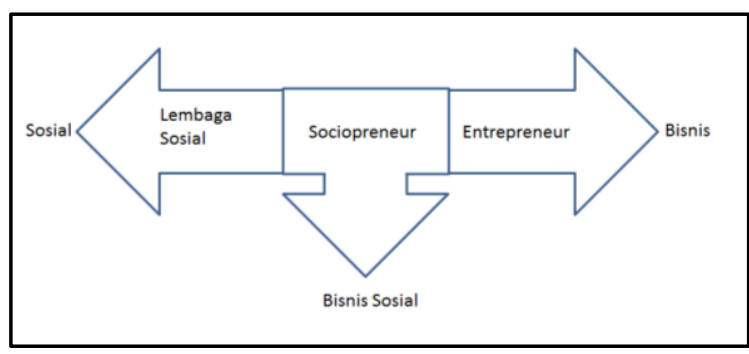

Gambar 3. Ilustrasi hubungan sociopreneur dengan Entrepreneur dan lembaga sosial
Dari gambar diatas dapat dilihat bahwa sociopreneur memiliki hubungan dengan lembaga sosial dan entrepreneur dimana sociopreneur menjalankan usaha bisnis yang hampir sama dengan entrepreneur namun memiliki orientasi bisnis untuk kepentingan sosial seperti yang dijalankan lembaga sosial.

"Teknologi informasi merupakan kombinasi teknologi komputer yang terdiri dari perangkat keras dan lunak untuk mengolah dan menyimpan informasi dengan teknologi komunikasi untuk melakukan penyaluran informasi” (Faizal, 2018).

\section{Perkembangan Sociopreneur di Indonesia}

Dalam sejarah Indonesia tercatat bahwa banyak organisasi pemuda atau serikat yang merupakan cikal bakal sociopreneur modern saat ini diantaranya Serikat Dagang Islam, Sekolah Kartini, Taman Siswa, Muhammadiyah dan Nahdatul Ulama.

Organisasi organisasi kala itu dibentuk untuk membantu masyarakat pribumi yang sangat kurang dalam segi pendidikan dengan dibentuknya organisasi tersebut dimasa penjajahan diharapkan masyarakat biasa yang bukan bangsawan dapat memiliki kesempatan mengenal pendidikan, untuk dapat menjalankan usahanya pun para penggagasnya harus membutuhkan dana yang tidak sedikit.

Selanjutnya kegiatan sosial ini pun berkembang di Indonesia seiring dengan perkembangan zaman dan perkembangan tingkat pendidikan masyarakatnya, meskipun pembangunan telah digalakkan diberbagai bidang namun untuk merata keseluruh pelosok tanah air membutuhkan waktu yang lama. Di berbagai daerah muncul organisasi organisasi yang dikelola akademisi baik mahasiswa mahasiswi atau orang orang yang berjiwa sosial yang mengarah pada pendidikan, kesehatan dan perekonomian untuk masyarakat di daerah yang sulit dijangkau atau yang berada dilingkungan keluarga tidak mampu.

Beberapa sociopreneur yang menginspirasi di Indonesia diantaranya :

1. Muhammad Abdul Karim, seorang sociopreneur muda yang menggagas Sahabat Pulau dan HUB Tasikmalaya. Sahabat Pulau adalah organisasi berbasis aksi kepemudaan yang bertujuan menyelesaikan masalah pendidikan pemuda dan anak-anak di seluruh Indonesia. Dan HUB Tasikmalaya adalah sebuah wadah, agar anak-anak muda Tasik bisa saling berbagi ide dan membuat inovasi yang bisa dikontribusikan kepada kota Tasikmalaya.

2. Dompet Dhuafa, digagas oleh wartawan senior yaitu Parni Hadi, Eri Sudewo dkk yang bergabung menjadi dewan pendiri lembaga Independen Dompet Dhuafa. 
Dalam pelaksanaannya dompet dhuafa mendirikan lembaga kesehatan dan rumah sakit gratis.

3. Ronny Poluan, founder dari Jakarta Hidden City Tour, dimana ide yang dimilikinya diluar dari bayangan yang ada dibayangkan selama ini tentang wisata kota selama ini kota yang dikunjungi adalah kota yang memiliki keindahan alam dan tempat hiburan yang mewah, konsep Jakarta Hidden City adalah tour ke tempat kumuh di sisi lain warga di lingkungan kumuh tentu mendapatkan manfaat ekonomis dari bagi hasil dari tour.

4. Nadiem Makarim, penggagas ojek online ini menjadikan profesi ojek tidak lagi dipandang sebelah mata dengan di fasilitasi aplikasi online, luarbiasa gagasan ini mendapat respon luar biasa dan melahirkan perubahan.

\section{Yayasan Mata Pena Sebagai Cikal Bakal Sociopreneur di Era Disruptif}

Menjadikan niat baik menolong sesama menjadi sebuah usaha yang dapat menghasilkan keuntungan yang nantinya digunakan untuk meningkatkan taraf hidup masyarakat yang membutuhkan adalah merupakan hal yang ingin diraih oleh Yayasan Mata Pena, didirikan oleh Syafei yang juga pengelola komunitas yang peduli pada pendidikan anak jalananan yang dikenal dengan nama KOPPAJA. KOPPAJA ( Komunitas Peduli Pendidikan Anak Jalanan ) merupakan sebuah komunitas yang dimana anggotanya tergabung dai kalangan mahasiswa mahasiswi di Indonesia. Awal mula Komunitas ini berdiri karena adanya rasa solidaritas yang tinggi kepada anak - anak yang kurang beruntung baik dalam kebutuhan materi ataupun pendidikan, khususnya anak jalanan.

Yayasan Mata Pena ini menggerakkan mahasiswa dan relawan untuk peduli pada pendidikan anak jalanan dengan memberikan pelatihan komputer dan kesenian, seiring berjalannya waktu dan kebutuhan yang dikeluhkan anak anak jalanan yang mulai tumbuh dewasa dan sebagian sudah berkeluarga diusia muda dengan kebutuhan yang semakin meningkat serta isu demografi yang mulai didengungkan yang diperkirakan lonjakan jumlah penduduk semakin meningkat dengan tingkat pengangguran yang juga diperkirakan mengalami lonjakan menjadikan syafei mulai menggagas sebuah ide untuk menghasilkan produk yang dapat dijadikan penghasilan tambahan bagi anak didiknya yang telah beranjak dewasa yang selanjutnya diikut sertakan dalam produksi dan pemasaran.

Melalui pengalaman di bidang manajemen yang didapatnya saat menjadi General Manager sebuah perusahaan makanan Syafei memulai produksi sabun cuci piring di pertengahan bulan April 2018 ini.

Untuk dapat bertahan di era disruptif yayasan mata pena harus memiliki inovasi yang dapat membawa perubahan yang tidak hanya mampu memberikan pendidikan bagi anak didiknya namun harus mampu merubah karakter dan taraf hidup mereka untuk keluar dari lingkaran garis kemiskinan dan kehidupan yang tidak layak, karena perubahan itu dihasilkan bukan diturunkan dan harus dipacu dengan semangat yang pantang menyerah dan tentunya dengan tidak mengesampingkan adanya support dari pemerintah dan lingkungan sekitar.

\section{Penggunaan Sosial Media dalam Pemasaran Produk}

Tidak dapat dipungkiri lagi bahwa saat ini teknologi informasi sangatlah berperan dalam aktifitas seharihari, begitupun dalam sosiopreneurship. Dengan adanya peran Teknologi Informasi dalam Sosiopreneurship diharapkan dapat memecahkan persoalan bagi dirinya sendiri maupun bagi orang lain, bukan hanya dengan pemanfaaatan teknologi mutakhir tapi juga dengan cara pandang yang mutakhir sehingga dapat mengahasilkan suatu karya, jasa atau produk yang lebih bernilai.

Pemanfaatan teknologi informasi dalam sosiopreneurship pada era digital saat ini berfokus pada penggunaan internet dan jejaring sosial. Internet dan jejaring sosial sebagai penunjang aktivitas sosiopreneurship agar lebih optimal karena dapat membantu sociopreneur untuk menginformasikan kegiatannya ke daerah yang sulit dijangkau, sehingga lebih banyak lagi orang yang mengetahui kegiatan tersebut.

Dalam menjalankan sosiopreneurship, KOPPAJA juga memanfaatkan teknologi infomasi yang sangat membantu mensukseskan kegiatannya dan membuka peluang untuk mendapatkan peluang pasar, salah satunya dengan menggunakan sosial media. KOPPAJA memiliki sosial media Facebook dan Instagram yang digunakan untuk mempromosikan berbagai kegiatan yang dilakukan. Hal ini tidak hanya membantu meningkatkan promosi kegiata tersebut, tetapi juga embangun branding KOPPAJA sebagai komunitas yang aktif mengadakan kegiatan setiap bulannya.

Manfaat penggunaan teknologi informasi juga dirasakan KOPPAJA untuk membangun networking yang luas, baik dengan pihak sponsor maupun volunteer yang ingin bergabung dengan kegiatan yang dilaksanakan oleh KOPPAJA. Saat ini cakupan kegiatan KOPPAJA masuk ke dalam skala lintas kota. Diharapkan dengan pemanfaatan teknoogi 
informasi ini kegiatan KOPPAJA bisa mencapai skala nasional dalam beberapa tahun ke depan.

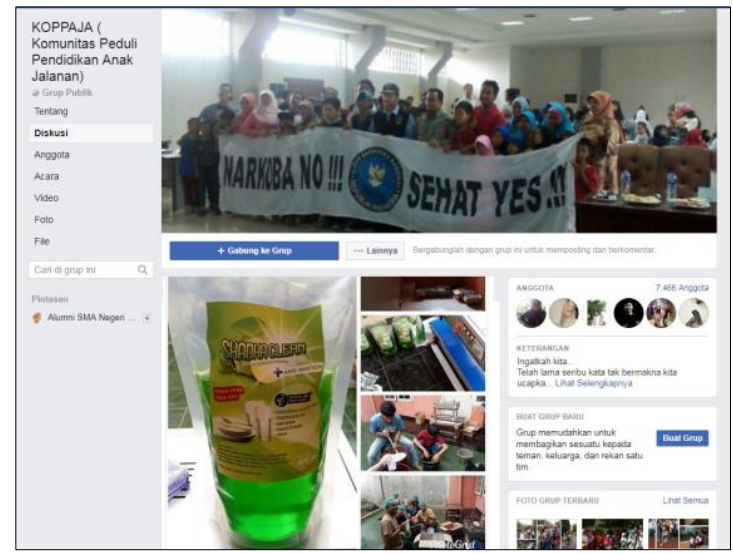

Gambar 4. Tampilan beranda facebook KOPPAJA Bogor

Untuk menjaring komunikasi lebih luas dengan sukarelawan atau donatur koppaja juga memiliki akun di instagram dengan nama wilayah masing masing salah satunya koppaja_bogor

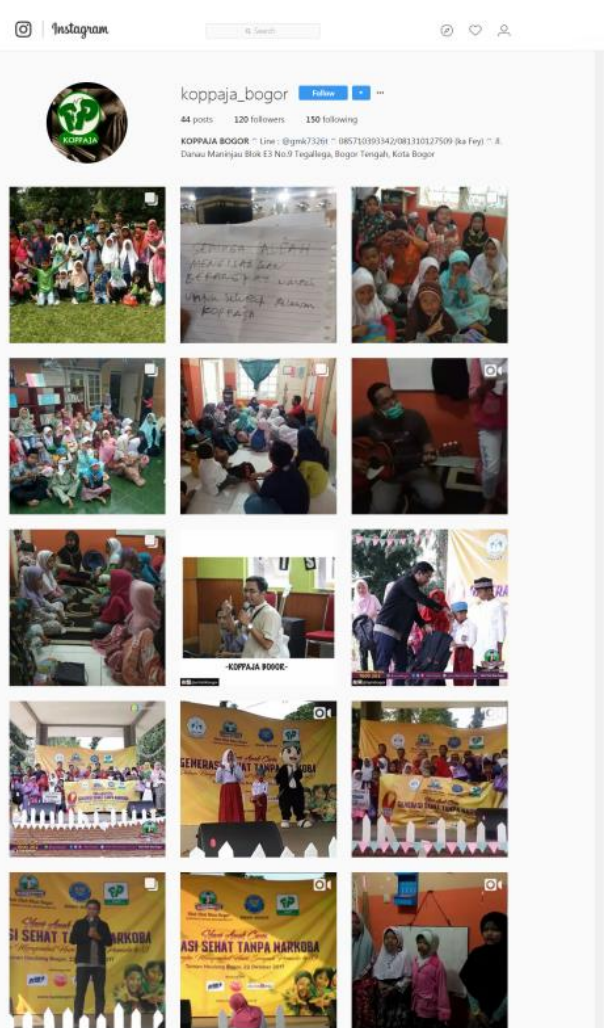

Gambar 5. Tampilan beranda facebook KOPPAJA Bogor
Sosial media tidak terbatas hanya pada aplikasi facebook atau Instagram saja namun promosi produk dapat dilakukan melalui munculnya informasi produk melalui pemberitaan di portal berita ataupun blog sehingga pembaca blog tersebut tertarik untuk membeli produk yang ramai diberitakan tersebut

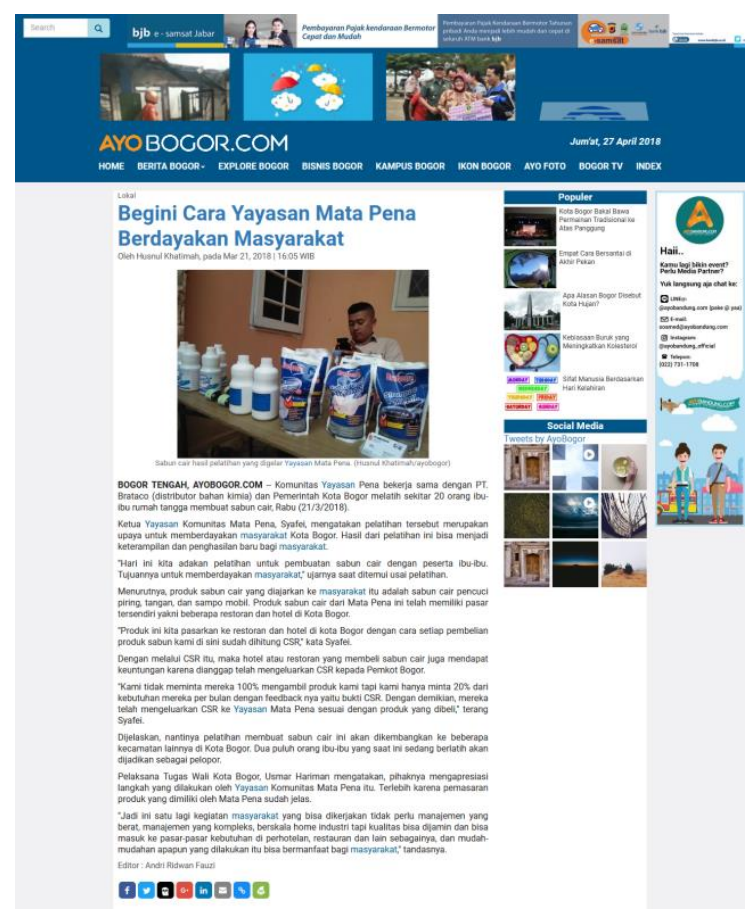

Gambar 6. Tampilan Pemberitaan Kegiatan Yayasan Mata Pena di Ayobogor.com

Demikian pula dengan pemberitaan di web pemerintahan dengan bekerjasama dengan pemerintah terkait tentunya dapat membuka peluang bagi seorang sociopreneur mengembangkan usahanya dan bergabung dalam program pemerintah 


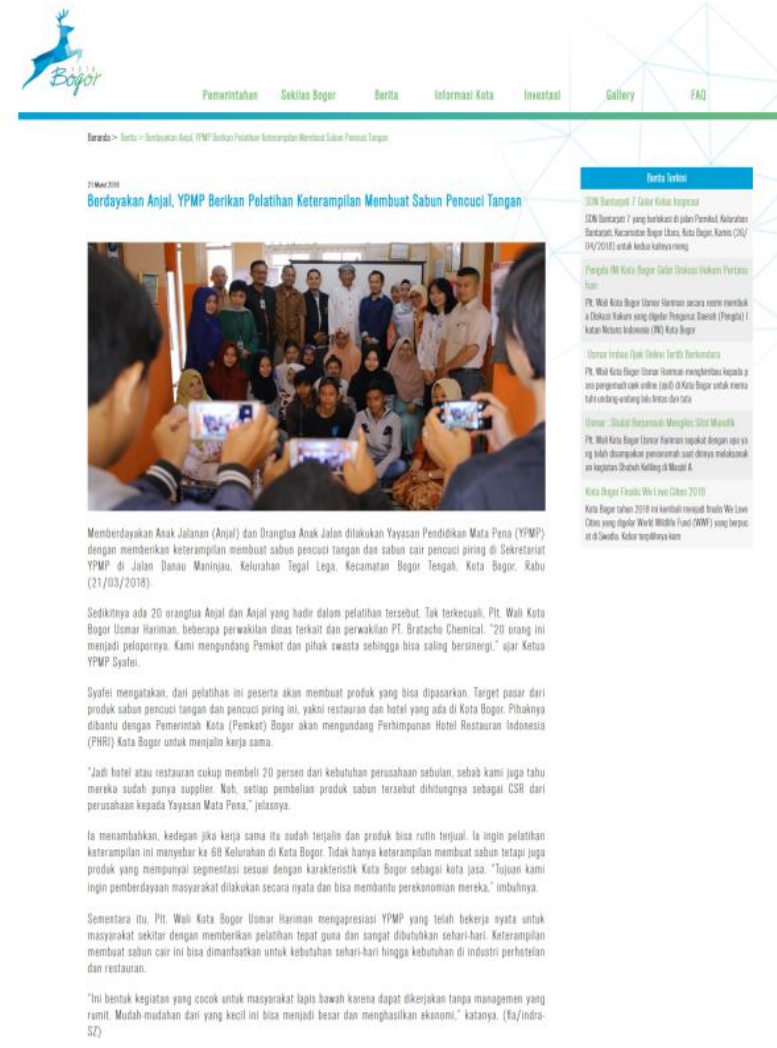

Gambar 7. Tampilan Pemberitaan Kegiatan Yayasan Mata Pena di web pemerintahan kota bogor

Begitu banyak hal yang harus dikembangkan oleh yayasan mata pena untuk dapat mengembangkan usahanya diantaranya saat ini yayasan ini masih dalam proses pengembangan sistem informasi berbasis web dan melakukan peningkatan dalam produksi dengan pembelian alat produksi dan memberikan kesempatan pada anak asuh dan orang tuanya untuk menjadi tenaga produksi dan marketing serta bekerja sama dengan pemerintah sehingga kegiatan yang dilakukan yayasan mata pena ini mendapatkan dukungan sebagai wujud usaha mengurangi kesenjangan atau permasalahan sosial yang ada di masyarakat.

Untuk menjadi sociopreneur yang dapat berkembang di era distuptif harus memiliki pemikiran yang dapat menciptakan perubahan dan dapat memberi pengaruh yang baik di lingkungan tempat usaha dikembangkan dan bagi masyarakat yang menjadi target perubahan itu sendiri.

\section{Rancangan Tampilan Web Yayasan Mata Pena}

Untuk lebih memudahkan bagi setiap donatur atau relawan atau lebih mengenalkan tentang yayasan mata pena di masyarakat untuk itu dibuatkan rancangan web yang nantinya dapat digunakan untuk kelangsungan kegiatan yayasan, adapun tampilan dari web tersebut terdiri dari halaman depan web dimana nantinya ditampilkan menu login untuk

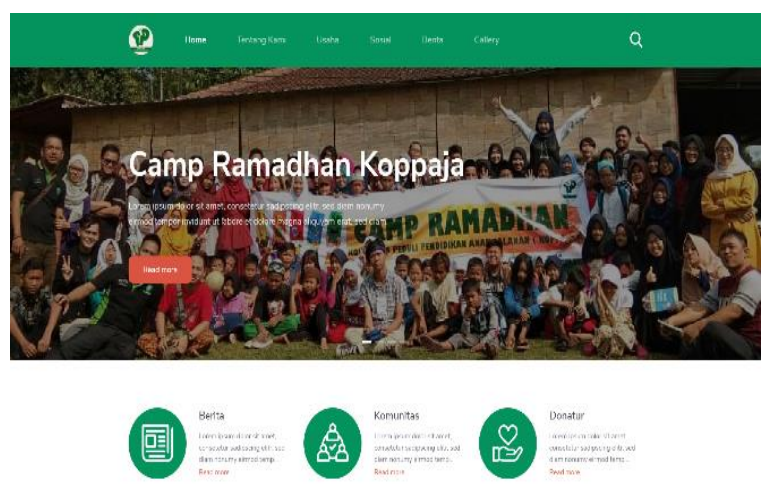

Gambar 8. Tampilan Halaman Depan Web

Tampilan ini adalah halaman muka web yang menampilkan beberapa menu yang bisa dipilih diantaranya donatur untuk masuk ke halaman donatur, untuk melihat berita ada menu berita dan untuk masuk ke halaman komunitas bisa dipilih lewat menu komunitas

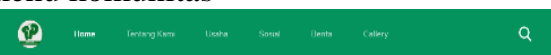

Gambar 9. Tampilan Halaman Login Donatur

Ini adalah tampilan login untuk donatur yang ingin menyalurkan bantuannya melalui yayasan mata pena. 

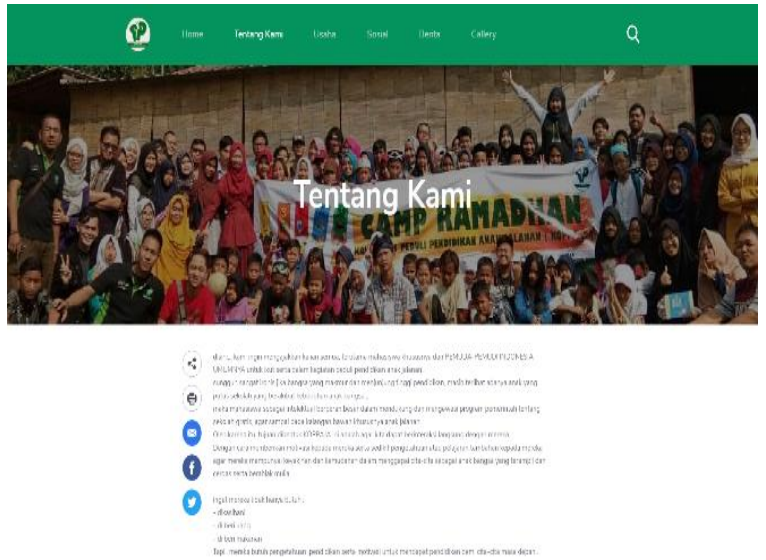

Gambar 10. Tampilan Halaman Tentang Yayasan Mata Pena

Halaman ini adalah halaman yang berisi tentang sekilas pengenalan tentang yayasan mata pena.
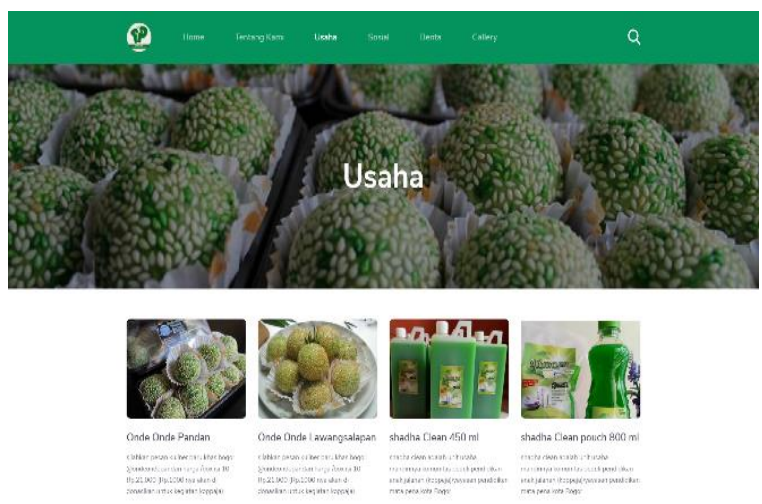

Gambar 11. Tampilan Halaman Usaha

Beberapa tampilan diatas adalah contoh hasil usaha yayasan mata pena yang ditampilkan dalam halaman usaha.
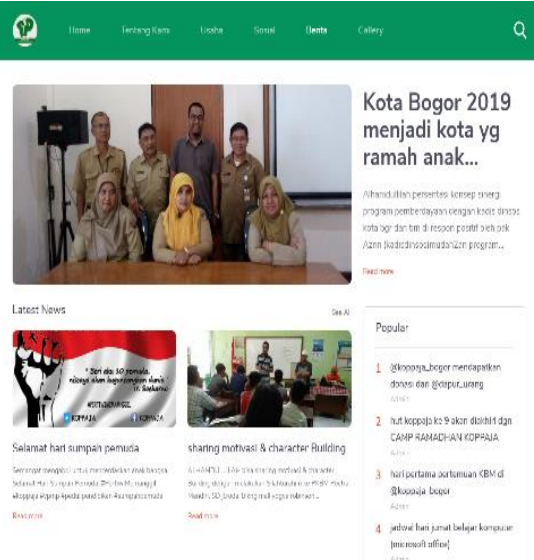

Gambar 12. Tampilan Halaman Berita
Segala sesuatu bentuk publikasi digital dari kegiatan yang diliput ditampilkan dalam halaman berita untuk menyampaikan pada masyarakat agar lebih mengenal kegiatan yang dilakukan oleh yayasan mata pena dan komunitas didalamnya.

\section{KESIMPULAN}

Membangun usaha dengan mengatasnamakan kesejahteraan bersama dan jauh dari kata mencari keuntungan bukanlah hal mudah namun tidak terlalu sulit karena segala hal yang berkaitan dengan kemanusiaan tentunya banyak pihak yang akan turut membantu diantaranya dapat disertakan dalam program khusus pemerintah setempat. Sebagai usaha yang mengandalkan produksi dan pemasaran tentunya sociopreneur juga membutuhkan media untuk memperkenalkan produknya ke pasar dalam hal ini sebagai usaha yang berkaitan dengan peningkatan taraf hidup anak jalanan tentunya dengan membeli otomatis turut mendonasikan hal tersebut dapat diuraikan dalam media sosial atau media online seperti web khusus yayasan mata pena sehingga selain konsumen para donatur dan relawan juga dapat ikut serta dalam mensejahterakan anak anak jalanan di daerahnya.

\section{REFERENSI}

Faizal, M. (2018). DAMPAK PERKEMBANGAN TEKNOLOGI INFORMASI TERHADAP PRODUKTIVITAS KERJA KARYAWAN. JURNAL SOCIO PRENEUR, 1(2), 48-57. Retrieved from http://ejurnal.kridatama.ac.id/index.php/js/artic le/view/14/pdf

Gandhi, T., \& Raina, R. (2018). Social entrepreneurship: the need, relevance, facets and constraints. Journal of Global Entrepreneurship Research, 8(1), 9. https://doi.org/10.1186/s40497-018-0094-6

Kennedy, posma sariguna johnson. (2017). Literature Review: Tantangan terhadap Ancaman Disruptif dari Financial Technology dan Peran Pemerintah dalam Menyikapinya, (2), 171-182

Malilang, C. S. (2008). Penanaman Nilai dan Moral pada Anak sebagai Modal Sociopreneur Melalui Mendongeng, 13-22.

Surniandari, A. (2017). Viral Marketing Sebagai Alternatif Strategi Pemasaran Produk Sariz. 
Widya Cipta-Jurnal Sekretari Dan Manajemen, 1(1), 35-43.

\section{PROFIL PENULIS}

Artika Surniandari, M.Kom. Pengajar di Universitas Bina Sarana Informatika, lulus Magister Komputer tahun 2010
Hilda Rachmi, M. Kom. Pengajar di Universitas Bina Sarana Informatika lulus magister di tahun 2015

Ahmad Al Kaafi, M. Kom. Pengajar di Universitas Bina Sarana Informatika, lulus Magister Komputer di tahun 2015

Amir, M. Kom. Pengajar di Universitas Bina Sarana Informatika, lulus Magister Komputer di tahun 2016 